\title{
MEMBACA STRATEGI EKSISTENSI LGBT DI INDONESIA
}

\section{IMRON MUTTAQIN}

Program Studi Manajemen Pendidikan

UIN Maulana Malik Ibrahim Malang

Imron.muttaqin@gmail.com

\begin{abstract}
LGBT is a deviance through mass media and social based, and specific researches about gender. Nonetheless, there is a bidden agenda to support some communities that argue their ontology, axiolog, and epistemology. Furthermore, the narrative argument developed by pro LGBT side has considerably changed the buman nature. Thus, this thought should be rectified wisely in order to avoid unnecessary issues. Moreover, based on the researches on the text media, LGBT promotes their activities through some ways. 1) Reinterpret the verses about LGBT by creating a counter-interpretation and bringing it up on the contemporary context. 2) Use the research based that is performed by the scientists to legalize their ideas. 3) Utilize the bumanrights as a legal protection. 4) Engage with gender issue as an initial point to catch the public opinion. 5) Handle the printed media. 6) Control the electronic media. 7) Work on social media.
\end{abstract}

Keywords: LGBT, Media, Promotion, Public Opinion

\section{PENDAHULUAN}

Blow up yang cukup viral LGBT di media baik cetak maupun elektronik menemukan momentumnya setelah sekian lama berusaha eksis dan mendapatkan legitimasi. Suatu fakta perkembangan yang asalnya bergerak senyap karena tingginya resistensi masyarakat mulai memasuki babak baru.Setidaknya pada zaman media sosial yang dapat digunakan menyebarkan infomrasi tanpa sensor yang berarti. Dengan menyebar dan meratanya informasi tersebut maka tak pelak lagi terjadi perang argumen dan interpretasi terhadap dalil-dalil yang dipakai dalam Al-Quran terkait LGBT begitu jelas terjadi, dalil naqli sebagai otoritas tertinggi terutama kisah Nabi Luth As dianggap salah tafsir dan out of date oleh pro-LGBT, mereka memakai argumen rasio, diksi dan hasil riset terkini meski terkesan mentah dan dipaksakan untuk meruntuhkan basis filosofis yang ada dalam Al-Qur`an. Kemapanan tafsir yang selama ini dijadikan rujukan dipertanyakan dengan alasan tidak sesuai dengan zaman.

LGBT yang mulai berani terang-terangan menunjukkan eksistensinya mengindikasikan bahwa mereka telah terdukung oleh makro sistem yang memuluskan jalannya. Maraknya isu ini menjadi menarik dikaji karena banyak bersinggungan dengan isu HAM yang notabene-nya adalah fitrah manusia. Tulisan ini membahas tentang pengertian, kontroversi mulai dari perang wacana media, pemikiran serta respon NU dan Muhammadiyah terhadap LGB sebagai organisasi dengan basis massa terbesar di Indonesia.

Terdapat perbedaan mencolok antara HAM versi barat dengan HAM versi Islam, HAM merupakan hak yang dimiliki oleh semua manusia dan semua umat manusia memiliki hak ini. ${ }^{1}$ Selain itu pula penafsiran HAM juga bervariasi antar Negara, jadi melanggar HAM di Amerika, tidak berarti melanggarnya di Indonesia karena penafsiran HAM tergantung pada situasi sosial, hokum dan budaya masyarakatnya, hal ini sesuai dengan pendapat Satjipto Rahardjo yang mengatakan bahwa apabila

${ }^{1}$ Philip Alston, The United Nations and Human Rights: An Appraisal, (Oxford University Press. 1990), hlm.10. 
seseorang telah melanggar HAM di suatu Negara maka belum tentu dia melanggarnya pada Negara lain pada kasus yang sama. ${ }^{1}$ Diantara perbedaan antara HAM barat dengan HAM Islam yang terpenting adalah konsep hifdhun al-null, konsep ini seringkali diingkari oleh penggiat HAM barat yang pro terhadap LGBT sehingga tampak jelas pada perang pola pikir yang terjadi, hak asasi setiap manusia adalah menjaga kelangsungan hidup keturunannya atau calon keturunan namun hak ini akan sirna manakala dukungan terhadap LGBT terus dilakukan. LGBT bertentangan dengan fitrah manusia sebagai makhluk sosial yang berkembang dan berperadaban, dan juga bertentangan dengan hak asasi manusia itu sendiri.

LGBT didanai oleh UNDP, dimulai pada bulan Desember 2014 hingga September 2017 yang bertujuan memajukan kesejahteraan lesbian, gay, biseksual dan intersek (LGBTI), kucuran dana sebesar USD 8 juta atau sekitar 107,8 Milyar itu untuk mendukung komunitas LGBTI di Indonesia. UNDP menerangkan bahwa inisiatif ini merupakan kolaborasi dengan masyarakat sipil, lembaga nasional dan regional untuk memajukan hukum dan kebijakan protektif.'Indonesia merupakan tempat yang memungkinkan tumbuh suburnya LGBT, banyak para akademisi yang mendukung isu LGBT dan memperbolehkan perkawinan sesama jenis, diantaranya adalah Musdah Mulia, yang oleh Adian Husaini dianggap cara berpikirnya sudah kacau sejak awal, ${ }^{3}$ begitu pula Nurofiah dia menyebutnya telah "keblinger" dalam cara pikir, sedangkan kaum pro LGBT menganggap bahwasanya golongan yang tidak mendukung sebagai golongan yang "ketinggalan zaman"dan tidak up to date,yang dimaksud dengan golongan ini termasuk diantaranya MUI (Majlis Ulama Indonesia), NU, Muhammadiyah, HTI, FPI dan sebagainya dianggap memakai hukum yang sudah usang dan tidak up to date dengan hasil riset terbaru.

Perang pemikiran (ghaspul fikr) mempunyai dampak yang lebih besar terutama bagi generasi muda karena yang diserang adalah logika pikir dimana paradigma yang menentukan motif, langkah dan gerakan diotak-atik dengan argumen rasional atau di blow-up agar tampak rasional. Dalam perang pemikiran ini, otoritas teks $A$ l-Qur an dan al-sunnah dijadikan perdebatan oleh kalangan pro dan kontra tentang LGBT, ada sebagian yang mengendus ayat-ayat tentang LGBT, tetapi ada pula pihak yang menyatakan bahwa dalam Al-Qur'an tidak ada yang konkret tentang LGBT, hanya intepretasi dari para Mufassir saja katakanlah disitu ada duo-jalal (jalalain), Ibnu Katsir dan lainnya.

Afirmasi hukum LGBT melalui pendidikan digugat dan juga dimasuki untuk dicari kelemahannya, ada juga pihak yang berusaha melucuti basis represifitas dalam Islam yang hampir selalu LGBT dikaitkan dengan kisah kaum Nabi Luth, AS. Para penggiat pro-LGBT berargumen dengan penelitian Murray (1977) yang menyebut bahwa pada umat Luth As, praktek lesbianisme sudah menjamur 40 tahun sebelum diambil alih oleh laki-laki, dan juga pendapat Boswell (1980) yang menyatakan bahwa pada batas tertentu masyarakat muslim bisa mentolelir kehidupan lesbian. Riset Samar Habib (2007) yang menemukan bahwa homeseksualitas perempuan di dunia Arab bukanlah sesuatu yang dianggap tabu hingga abad 13. Kalangan pro LGBT menganggap bahwa cara memberangus hegemoni LGBT dalam Islam melalui pengetahun (pendidikan) dimana "LGBT" dikuasa wacanakan sebagai pendosa dan melawan kehendak alam. Mereka juga menganggap orang

\footnotetext{
${ }^{1}$ Satjipto Rahardjo, Sosiologi Hukum, (Yogyakarta: Genta Publishing. 2002), hlm. 108-114.

2http:/ /international.sindonews.com/read/1084674/40/dana-melimpah-rp107-8-miliar-untuk-lgbtindonesia-3-negara-asia-1455237677

${ }^{3}$ Musdah Mulia adalah salah satu guru besar bidang pemikiran Islam di UIN Syarif Hidayatullah Jakarta. Lihat https://www.arrahmah.com/read/2008/04/02/1722-prof-uin-jakarta-halalkan-homoseksual .html.
} 
yang "kontra" telah merebut tafsir teks suci tersebut dan dioperasionalisasikan melalui institusi keagamaan dan pendidikan seperti pesantren dan sekolah, begitu juga kaum gay dan transgender.

\section{PENGERTIAN LGBT}

Pengertian LGBT akan diuraikan terlebih dahulu untuk menyamakan persepsi tentang LGBT. Banyak sekali istilah-istilah yang dipakai berkaitan dengan isu gender ini, oleh karena itu agar terdapat kesamaan persepsi, dalam bab ini diuraikan pengertian masing-masing. Istilah yang berkaitan dengan LGBT adalah homoseksual, yaitu seseorang yang cenderung mengutamakan orang yang berjenis kelamin sama sebagai mitra seksual disebut homoseksual, ${ }^{1}$ senada dengan arti tersebut Oetomo mendefinisikan sebagai orientasi atau pilihan seks yang diarahkan pada seseorang atau orang-orang dari jenis kelamin yang sama atau ketertarikan seseorang secara emosional dan seksual kepada seseorang atau orang-orang dari jenis kelamin yang sama. ${ }^{2}$ Dari kedua pendapat tersebut dapat disimpulkan bahwa homoseksual merupakan orientasi atai pilihan dari seseorang yang ditujukan pada individu atau beberapa individu dengan jenis kelamin yang sama. Homoseksual lakilaki disebut dengan "gay" sedangkan homoseksual perempuan disebut "lesbian".

Lesbian, adalah istilah bagi perempuan yang mengarahkan orientasi seksualnya kepada sesama perempuan, selain itu juga diartikan wanita yang mencintai atau merasakan rangsangan seksual sesama jenisnya, wanita homoseks. ${ }^{3}$ Istilah ini juga merujuk kepada perempuan yang mencintai perempuan baik secara fisik, seksual, emosional, atau secara spiritual.Gaymerupakan istilah yang digunakan untuk menggambarkan seorang pria yang secara seksual tertarik kepada sesama pria dan menunjukkan pada komunitas yang berkembang diantara orang-orang yang mempunyai orientasi seksual yang sama. Istilah gay biasanya dikontraskan dengan straight.Biseksual adalah istilah yang digunakan untuk menggambarkan orang-orang yang tertarik kepada dua jenis kelamin sekaligus, jadi tipe ini tertarik pada laki-laki juga tertarik pada perempuan.

Transgender merupakan istilah untuk orang yang cara berperilaku atau penampilannya tidak sesuai dengan jenis kelaminnya, misalnya cowok tetapi tingkahlaku dan sikapnya seperti cewek, bahkan berpakaiannya pun seperti cewek atau sebaliknya. Sedangkan transeksual berbeda dan transgender, transeksual adalah orang yang merasa identitas gendernya berbeda dengan orientasi seksualnya, orang ini merasa bahwa dirinya terjebak pada tubuh yang salah. LGBT dilihat dalam perspektif psikoanalitik dan budaya termasuk kategori BPD (Borderline Personality Disorder) yang menunjukkan bahwa masalah identitas gender dan budaya pada masyarakat transisi, hal ini diungkap oleh C. Silverstein, ${ }^{4}$ dan memang benar pada saat ini memang sedang menjadi isu besar kalangan pro LGBT yang mengarahkan isu sentral menjadi hak asasi dan berusaha mendapatkan posisi.

\section{RESPON ISLAM TERKAIT LGBT}

Dua ormas (organisasi kemasyarakatan) terbesar di Indonesia ini sama-sama menolak LGBT, Menurut NU LGBT merupakan bentuk penyimpangan dari fitrah kemanusiaan. Dalam pernyataan sikap resminya, NU yang diwakili oleh Kyai Miftah PBNU menolak tegas paham atau kelompok yang

${ }^{1}$ Haryanta, Agung Tri. Sujatmiko, Eko. Kamus Sosiologi, (Surakarta. Aksara SInergi Media. 2012), hlm. 85.

2Oetomo, Dede.Memberi Suara Bagi Yang Bisu, (Yogyakarta: Galang Printika. 2001), hlm. 6.

${ }^{3}$ Kamus Besar Bahasa Indonesia. Versi 1.5

${ }^{4}$ Silverstein, C. The Borderline Personality Disorder and Gay People, (Journal of Homosexuality, 15 (1-2), 1998), hlm. 185-212. 
membolehkan atau mendukungnya termasuk aliran dana dan yang mengakui eksistensi LGBT, ${ }^{1}$ NU menyerukan agar masyarakat bekerjasama menyediakan layanan rehabilitasi bagi kalangan LGBT, begitu juga badan otonomi NU, seperti IPNU Jombang, IPNU Cirebon, Ansor/Banser, Muslimat Brebes. Senada dengan itu, Muhammadiyah menganggap LGBT merupakan pelanggaran terhadap HAM. $^{2}$ Prinsip hak asasi manusia menurut kedua organisasi masyarakat terbesar di Indonesia ini adalah "menjaga keturunan" (hifd an-nash) dengan begitu LGBT sangat bertentangan dengan prinsip tersebut sehingga harus ditolak.

Respon organisasi kemasyarakatan di Indonesia seperti NU dan Muhamadiyah menolak dengan tegas LGBT dan semua hal yang mendukungnya, begitu pula para tokoh pendidi kan di Indonesia, menganggap LGBT sebagai bentuk penyimpangan, oleh karena itu pemerintah harus tegas dalam mengatur eksistensi LGBT di Indonesia, para pelakunya perlu direhabilitasi agar kembali ke fitrahnya sebagai manusia yang heteroseksual, LGBT itu melanggar Hak Asasi Manusia (HAM) karena bertentangan dengan hak dasar manusia.

Steven D. Johnson, mendukung kedua ormas Islam ini dan menyarankan bahwa para praktisi sosial yang berkaitan dengan rehabilitasi LGBT agar mempunyai kemampuan terapi afirmasi (affirmative theraphy) sebagai kompetensi kulturalnya. ${ }^{3}$ Kemampuan ini sangat penting untuk menyadarkan kaum LGBT dan mengembalikannya ke manusia yang heteroseksual. Dalam ilmu psikologi, homoseksual dibagi menjadi dua macam, yaitu tipe sistonik dan ego distonik. Tipe sistonik merupakan homoseksual yang sudah dari bawaan, sedangkan tipe ego distonik merupakan pengarung lingkungan, teman, dan variabel lain yang mendukung terbentuknya identitas.

Ada dua macam LGBT, alami dan jadi-jadian. LGBT yang alami jumlahnya tidak banyak, inilah yang dulu ada pada zaman Rosulullah SAW, namun yang banyak muncul saat ini adalah LGBT jadi-jadian, pria tetapi berlagak wanita, dan wanita berlagak pria, Biseksual dan Transgender. Alasan ekonomi dan kecenderungan adalah lebih banyak tetapi dibingkai dalam retorika kata seperti jiwa wanita yang terjebak dalam tubuh laki-laki begitu pula sebaliknya. LGBT bertentangan dengan HAM yang ingin hidup damai dan normal seperti fitrahnya.

Adu paradigma dan argumen mengenai nash Al-Quran tentang aktifitas LGBT banyak digugat menggunakan interpretasi yang tidak rasional dan jauh dari makna sesungguhnya serta jauh dari kearifan lokal sebagai bangsa Indoensia. Penggiat LGBT dengan sedikit malu-malu dan canggung menggugat mulai dari histori (asbab al-nu₹ul dan asbab al-nurud) dengan pemakaian diksi dan paradigma pemikiran kekinian meskipun argumentasinya masih mentah dandipaksakan untuk melawan kemapaman Al-Qur’an.

Individu merupakan pusat dari identitas seseorang, apakah dia lesbian, gay, biseksual, atau transgender, penelitianDeanmenunjukkan bahwa orientasi seksual dan idetintitas gender merupakan pusat definisi diri, sedangkan level afiliasinya dengan anggota LGBT lain apakah menolak atau menerima sangat bervariasi antar individu. ${ }^{4}$ Jadi berpusat pada individu, yang berarti bahwa ucapan dan tindakan seseorang baik yang pro maupun kontra terhadap LGBT merupakan indikator terhadap

${ }^{1}$ http://www.nu.or.id/post/read/66045/resmi-pbnu-sikapi-perilaku-seksual-menyimpang-lgbt. Diakses pada 2 Agustus 2016.

${ }^{2}$ Baik NU maupun Muhammadiyah menolak dengan tegas LGBT yang mengatasnamakan hak asasi sebagai tameng memperkuat eksistensinya.

3Johnson, S. D, Gay Affirmative Psychotherapy With Lesbian, Gay, and Bisexual Individuals: Implications for Contemporary Psychotherapy Research, (American Journal of Orthopsychiatry, 82 (4). 2012), hlm. 516-522

${ }^{4}$ Dean, L., Meyer, I. H., Robinson, K., Sell, R. L., Sember, R., Silenzio, V. M. B., ... White, J. (2000). Lesbian, gay, bisexual, and transgender health: Findings and concerns. Journal of the Gay and Lesbian Medical Association (Vol. 4) 
apa yang terjadi dalam dirinya. Penelitian Delaet menunjukkan bahwa pernikahan gay merupakan "hak religius" seseorang yang perlu dilindungi di Amerika, karena mempunyai equal rights dengan pernikahan lainnya. ${ }^{1} \mathrm{Hal}$ ini jelas bertentangan dengan syariat Islam yang menjaga garis keturunan (bidzun nas).

\section{KARYA ILMIAH}

Tampaknya pada sisi ini kalangan kontra LGBT lemah karena jarangnya kajian dan penelitian menolak kecuali atas dasar justifikasi agama dan fitrah, hegemoni religi telah ditantang berdasarkan akal yang dikendalikan oleh nafsu tingkat rendah.

Eliason dan Roberson melalui penelitiannya menemukan bahwa angka diskriminasi terhadap kaum LGBT cenderung menurun, ${ }^{2}$ ini berarti lama kelamaan eksistensi LGBT bisa diterima oleh masyarakat. Penelitian ini memang mendeskripsikansebuah trend bahwa pada masa yang akan datang keberadaan LGBT makin bisa diterima oleh masyarakat di Amerika. Studi yang dilakukan J. Gedro juga menunjukkan celah atau posisi yang dilakukan oleh organisasi yang mempunyai pekerja LGBT, dia mengatakan bahwa berdasarkan hasil penelitiannya para praktisi HRD (Human resources development) dapat menunjukkan identitas organisasi terkait dengan kaum heteroseksual dan pengembangan karirnya. ${ }^{3}$ Begitu pula studi yang dilakukan oleh S. Campbelmenunjukkan bahwa menunjukkan bahwa kaum LGBT secara individu mempunyai kerentanan khusus terhadap penyakit seksual menular seperti HIV-AIDS, diskriminasi dan pemahaman yang buruk terhadap kesehatan seksual mereka dan hal ini menimbulkan keprihatinan kesehatan masyarakat bagi komunitas LGBT pada populasi yang lebih luas. ${ }^{4}$ Studi yang mendukung diterimanya eksistensi LGBT atau salah satu dari mereka dengan menghalalkan nikah sejenis seperti di Swedia dan salah satu Negara bagian di Amerika Serikat.

\section{MEDIA}

Bahasa dan kuasa, dalam terminologi kaum "Faucoult" memegang peran kunci dalam sosialisasi suatu konsep sehingga media merupakan piranti wajib yang digunakan untuk eksistensi pemikiran. Kebanyakan orang sudah faham bahwa media massa berperan besar dalam membentuk opini publik sekaligus pembentuk agenda (agenda setting) baik yang terang-terangan maupun tersembunyi. Kita semua tentu masih ingat pilihan presiden beberapa tahun silam, antara Jokowi dan Prabowo, perang media begitu kentara bahkan melibatkan kredibilitas lembaga survey yang saling menklaim kemenangan. Kalau kita melihat TV One dan ANTV dan lembaga survey yang digandengnya pasti yang menang adalah Prabowo, tetapi kalau kita melihat Metro TV, berdasarkan lembaga survey yang ada di Stasiun Televisi ini pasti Jokowi yang menang padahal instrumen statistik yang dipakai juga sama, tetapi ditangan kedigjayaan politik seolah menjadi tak berdaya karena harus memihak. Image Branding dibentuk oleh media massa dan disodorkan pada masyarakat untuk merubah dan mendapatkan opini. Pada sisi ini, betul apa yang dikemukakan Golding dan Murdoc bahwa media

${ }^{1}$ DeLaet, D. L., \& Caufield, R. P. Gay Marriage as a Religious Right: Reframing the Legal Debate over Gay Marriage in the United States. (Polity, 40 (3), 2008), hlm. 297-320.

${ }^{2}$ Eliason, M. J., Dibble, S. L., \& Robertson, P. A, Lesbian, Gay, Bisexual, and Transgender (LGBT) Physicians' Experiences in the Workplace, (Journal of Homosexuality, 58 (10), 2011), hlm. 1355-1371.

${ }^{3}$ Gedro, J, LGBT Career Development. Advances in Developing Human Resources, 11 (1). 2009), hlm. 54-66

${ }^{4}$ Campbell, S. Sexual Health Needs And The LGBT Community. Nursing Standard (Royal College of Nursing), (Great Britain : 1987, 27, 2013), hlm. 35-8 
massa telah menjadi industri yang menjual informasi yang membentuk pola pikir dan memandu perilaku konsumennya.

Pada tahun 2008, Michael King dan J. Semylen menggunakan meta-researh terhadap database journal internasional menunjukkan bahwa LGBT beresiko tertinggi terhadap mental disorder, ${ }^{1}$ penelitian ini menggunakan database riset pada Medline, Embase, Psycinfo, Cinabl, The Cocbrane Library Database, The Web of Knowledge, The Applied Social Sciences Index dan Abstracts, the International Bibliography of the Social Sciences, Sosiological Abstracts, Campbel Collaboration and Grey Literatures Database for Articles dan juga menggunakan Google Scholar serta mengontak langsung penulisnya untuk klarifikasi. Selain masalah kesehatan mental, penelitian E. Robert menunjukkan bahwa pelaku LGBT juga beresiko tertular $\mathrm{HIV}^{2}$

Pada sisi lain, artikel menarik yang ditulis oleh Po Lin Pang, J. Meng dan S. Zhou (2010) melalui riset content analytic study menginvestigasi dua surat kabar yaitu The New York Times dan Chicago Tribune, setelah adanya rekomendasi dari Massachuset hasilnya menunjukkan bahwa The New York Times menggunakan menggunakan isu legitimasi dan persamaan hak, sedangkan Chicago Tribune menggunakan isu pentingnya moralitas kemanusiaan. ${ }^{3}$ Jadi sangat jelas hubungan antara penggunaan hak asasi manusia dan moral yang mulai sedikit demi sedikit digeser orientasinya oleh media termasuk di Indonesia.Isu yang dijadikan pembahasan (cover intelektual) adalah isu persamaan hak, moral dan kebiasaan yang sudah terjadi sejak dulu.Sebagai issu sentral yang direncanakan secara masif, persamaan hak, hak asasi manusia dan moral ini sering dijadikan dalih pembenaran LGBT, selain itu didapatkan juga penggunaan media televisi untuk pembentukan opini. Kompas TV merupakan media elektronik yang berani menampilkan dialog LGBT memberikan ruang untuk eksis, ${ }^{4}$ sehingga menurut Yons Ahmad kompas TV telah menggiring opini bahwa LGBT tidak perlu dicemaskan. ${ }^{5}$ Pada media online kaskus juga terjadi perang narasi yang seru antar para netizen, tetapi ujung-ujungnya melebar kearah perda yang terkait dengan kearifan lokal (konvensi norma masyarakat).

Kalangan pro LGBT memberikan contoh di awal kehidupan di Madinah pada era Nabi Muhammad SAW telah terdapat waria (mukhannatun) yang paling terkenal namanya adalah Hit, dan mereka hidup membaur dengan masyarakat secara normal. Bahkan Sayyidatina A isyah R.A pernah meminta bantuan untuk menjadi comblang perjodohan kakaknya.Cerita mengenai hit ini dipergunakan oleh pro LGBT sebagai dasar padahal mereka adalah khunsa asli yang tidak bisa disejajarkan dengan hukum waria buatan yang saat ini menggurita. Jadi jelas tidak tepat jika digunakan sebagai alasan bahwa sejak zaman Nabi Muhammad, SAW sudah ada khunsa dan mereka diperlakukan dengan baik.

${ }^{1}$ King, M., Semlyen, J., Tai, S. S., Killaspy, H., Osborn, D., Popelyuk, D., \& Nazareth, I. A Systematic Review Of Mental Disorder, Suicide, And Deliberate Self Harm In Lesbian, Gay And Bisexual People, (BMC Psychiatry, 8, 2008), hlm. 70.

${ }^{2}$ Roberts, E, Lesbian, Gay, Bisexual, And Transgendered Youth Issues, (SIECUS Report, 29 (April/May). 2001), hlm. $37-42$.

${ }^{3}$ Pan, P. L., Meng, J., \& Zhou, S. Morality or equality? Ideological framing in news coverage of gay marriage legitimization. Social Science Journal, 47 (3), (2010).

${ }^{4}$ Kompas tv mendapatkan peringatan dari Komite Penyiaran Indonesia (KPI) Pusat atas programnya yang berjudul "LGBT, Haruskan Dicemaskan" yang ditayangkan pada tanggal 11 Februari 2016 dan mengingatkan bahwa penyiaran harus menjaga dan meningkatkan moralitas dan nilai-nilai agama serta jati diri bangsa., KPI juga melarang TV dan Radio menjadi corong LGBT di Indonesia.

5Islamedia. Jadi Corong Pro LGBT, Begini Cara Kompas TV Menggiring Opini. 13 Februari 2016. 
Tulisan pro LGBT diatas hanyalah memberikan gambaran bahwa sudah terdapat banci di zaman Nabi Muhammad SAW, tetapi hanya memberitakan sebagian kecil saja.Pada zaman Nabi memang telah ada waria, ada tiga yaitu Mati', Hidm dan Hit.Nama pertama (Mati') merupakan budak dari bibi Nabi yang bernama Fakhitah binti Amr yang seringkali datang kepada Nabi dan para istri beliau, namun pada akhirnya dilarang. Pelarangan ini yang tidak ditampilkan oleh para penggiat LGBT mereka hanya mengatakan bahwa dizaman Nabi telah ada waria bahkan sering datang ke para istri Nabi Muhammad, SAW, ini jelas pemutarbalikan fakta karena Nabi sendiri melarang para waria datang ke rumah beliau dan rumah kaum muslimin. Memang benar bahwa eksistensi waria bahkan dari zaman sebelum Nabi Muhammad SAW memang telah ada, tetapi selalu bertentangan dengan fitrah dan agama-agama samawi.

Pada perkembangan selanjutnya di masa Khalifah Sulaiman ibn Abdul atMalik (Dinasti Umayyah 715-716) marah dan memberikan perintah agar para waria yang menjadi penyanyi dikebiri. ${ }^{1}$ Perintah ini selain representasi dari penolakan terhadap waria juga lebih menegaskan sikap penentangan terhadap LGBT.

\section{HAM DAN KEMANUSIAAN}

Hak Asasi Manusia (HAM) seringkali dipakai sebagai alat melegitimasi perlindungan, namun tetap saja gagal dan cacat pelaksanaan karena cenderung membela subyek. Misalnya si A telah menganiaya si B sampai meninggal, maka si A tidak dihukum qisash sebagaimana perbuatannya karena mempunyai hak hidup, bukankah si B juga punya hak untuk hidup? Tetapi mengapa tidak disentuh sama sekali oleh HAM melainkan membela yang telah berbuat aniaya, lalu bagaimana jika keluarga si B juga menuntut bahwa si B juga punya hak hidup, lalu mengapa cuma si A yang punya hak hidup?

Tilaar mendefinisikan HAM sebagai hak-hak yang melekat pada diri setiap insan dan tanpa memiliki hak-hak itu setiap insan tidak bisa hidup selayaknya manusia, hak tersebut diperoleh sejak lahir ke dunia. Merujuk pendapat Tilaar ini, agaknya terlalu naif kalau dikatakan bahwa kebutuhan seks berdasarkan orientasi seksual merupakan hak asasi manusia.Orientasi seks merupakan pemberian dari tuhan, menurut bahasa kalangan pro LGBT, sehingga harus dimasukkan kategori hak asasi.

\section{DISKUSI}

Kalangan pro LGBT juga telah menggunakan ilmu-limu komunikasi sosial dan memahami cara setting agenda untuk memasukkan isu-isunya. Tulisan ini mencoba membedah alur komunikasi publik yang dilakukan oleh kelompok pro LGBT di Indonesia yang juga telah mencoba menginterpretasikan teks suci berbasis kekinian secara argumentatif.Kemapanan gender dan seksualitas berbasis agamadan fitrah telah berulangkali digugat dalam kredo dialektika argumentatif. Agaknya di Indonesia yang agak spesialis melakukan interpretasi ini adalah Musdah Mulia dan Aan Anshori.LGBT merupakan penyakit sosial dan psikologis, argumen dasar ini terus ditentang para peneliti barat bahwa LGBT bukanlah penyakit sehingga tidak perlu diobati, apabila diterima argumen ini jelas membuka celah penerimaan eksistensi.

Dalam Islam orang yang tidak jelas jenis kelaminnya disebut "khunsa", jumhur ulama menjelaskan khunsa adalah orang yang tidak jelas kelaminnya laki-laki atau perempuan, dan orang yang

${ }^{1}$ Aan Anshori. Membenci Banci. Kompasiana. Juni 2015. 
tidak punya alat kelamin sama sekali. ${ }^{1}$ Khunsa perlu diselidiki terlebih dahulu apakah asli atau jadijadian, yang saat ini banyak dipermasalahkan adalah para khunsa jadi-jadian, golongan inilah yang paling banyak menjadi masalah karena memakai nama gender yang sebenarnya untuk khunsa asli tetapi digunakan untuk menuntut hak dan persamaan.

Berdasarkan penjelasan data-data diatas, dapat diketahui strategi yang digunakan oleh pro LGBT untuk bisa diterima oleh masyrakat sebagai berikut;

Pertama, mempertanyakan kembali akar penolakan dari ayat Al-Qur`an dan Hadist. Ayat-ayat Al-Qur`an yang berbicara mengenai LGBT ditafsir ulang dan mempermasalahkan kembali konteks asbab al-nuгul yang tidak sesuai dengan kondisi sekarang. Kalangan pro LGBT mengidentifikasi bahwa nash Al-Quran merupakan sumber terkuat legitimasi yang dipakai para penolah LGBT sehingga akarnya harus dipermasalahkan.

Kedua, menggunakan tafsir sendiri atas ayat. Cara kedua ini banyak dilakukan pro LGBT yang punya pengetahuan tentang agama namun mempunyai orientasi yang berbeda dengan fitrak manusia sehingga terjadilah tafsir yang banyak berseberangan dengan epistemologi ilmu tafsir itu sendiri. Sebagai contoh, Khairul Anwar memberikan argumen bahwa semua dalil yang menolak LGBT bersumber dari QS. Al-A raf ayat 80-81 tentang cerita Nabi Luth AS, dia juga mengatakan bahwa LGBT dalam Qur`an justru mendapatkan tempatnya jika disadari bahwa itu adalah bawaan (QS. Al Isra` 84). Janji Al-Qur`an kepada masyarakat Arab masa Nabi Muhammad SAW tidak hanya bidadari atau hunian tetapi juga anak-anak muda berwajah tampan karena ketika Qur`an diturunkan banyak lelaki yang mempunyai hasrat seksual terhadap pemuda tampan.kata Luth disebutkan sebanyak 27 kali yang kesemuanya muncul dalam narasi kisah perjuangan rasul yang ditolak umatnya (QS. Hud 70, 77, 81, 89, QS. Al-Hijr; 59, 61, QS. Al-Hajj; 43, QS. Asy-Syura; 160, 161, 167, QS Al-Naml; 56, QS. Al'Ankabut; 26, QS, Shad; 13, QS. Qaf 13, QS. Al-Qomar 33, 34, QS. At-Tahrim: 10, QS. Al-An`am; 86, QS. Al-A `raf; 80, QS. Al-Anbiya: 71, 74, QS. An-Naml: 54. QS. Al-`Ankabut: 28, 32, 33 dan QS. Ash-Shaffat; 133). Hal ini menunjukkan bahwa kisah Nabi Luth AS, merupakan fenomena yang perlu mendapat perhatian khusus.

Ketiga, menggunakan isu HAM dan kemanusiaan, ini adalah salah satu strategi yang digunakan untuk mendapatkan legalitas hukum dan perlindungan karena bisa terkoneksi langsung dengan dunia internasional, hal yang sama juga terjadi di Amerika ketika mereka menyuarakan persamaan hak untuk kaum LGBT sehingga akhirnya perkawinan sesama jenis diperbolehkan di Amerika.

Keempat, isu gender juga digunakan sebagai instrumen eksistensi diri, mereka beralasan bahwa gender merupakan takdir, termasuk transgender dan orientasi seksual sehingga tidak bisa disalahkan.

Kelima, media cetak merupakan alat penyampai opini yang bagus karena dapat dibaca oleh samua lapisan masyarakat dan menyentuh semua kalangan sehingga efektif digunakan sebagai alat membentuk opini. Media cetak banyak yang mempromosikan atau minimal memberitakan kasus kasus LGBT.

Keenam,media elektronik. Termasuk di dalamnya adalah televisi dan radio dimana media ini cukup efektif mempengaruhi opini publik.

Ketujuh, media sosial seperti facebook, whatsapp, website, blog serta media sosial lainnyasebagai alat promosi ampuh yang digunakan pro LGBT untuk mempromosikan, menyiarkan dan memproklamirkan diri mereka.

${ }^{1}$ Khunsa yang asli memang salah satu kehendak dari Allah SWT, kebanyakan saat ini banyak disamarkan oleh penggiat LGBT menggunakan dalih bahwa khunsa merupakan takdir, begitu juga orientasi seksual, karena merupakan pemberian langsung maka menurut mereka tidak bisa dihakimi. 


\section{KESIMPULAN}

Berdasarkan analisis pada fenomena dan fakta yang muncul dapat disimpulkan bahwa upaya positioning LGBT di Indonesia, terdapat beberapa cara yang ditempuh yaitu; 1) menafsir ulang dalit dalil tentang LGBT dengan membuat tafsir tandingan atau membawanya pada konteks kekinian, 2) mendasarkan pada riset para peneliti dan menggunakannya sebagai alasan untuk legalisasi, 3) menggunakan isu HAM, 4) menggunakan isu gender sebagai langkah awal penggiringan opini publik, 5) menggunakan media cetak, 6)media elekronik dan 7)media sosial.

\section{REFRENSI}

Campbell, S. 2013. Sexual health needs and the LGBT community. Nursing Standard (Royal College of Nursing (Great Britain): 1987), 27, 35-8.http://doi.org/10.7748/ns2013.04.27.32.35.e7250

Dean, L., Meyer, I. H., Robinson, K., Sell, R. L., Sember, R., Silenzio, V. M. B., ... White, J. 2000. Lesbian, gay, bisexual, and transgender health: Findings and concerns. Journal of the Gay and Lesbian Medical Association (Vol. 4). http://doi.org/10.1023/A:1009573800168

DeLaet, D. L., \& Caufield, R. P. 2008. Gay Marriage as a Religious Right: Reframing the Legal Debate over Gay Marriage in the United States*. Polity, 40(3), 297-320. http://doi.org/10.1057/palgrave.polity.2300103

Eliason, M. J., Dibble, S. L., \& Robertson, P. A. 2011. Lesbian, Gay, Bisexual, and Transgender (LGBT) Physicians' Experiences in the Workplace. Journal of Homosexuality, 58(10), 1355-1371. http://doi.org/10.1080/00918369.2011. 614902

Gedro, J. 2009. LGBT career development. Advances in Developing Human Resources, 11(1), 54-66. http://doi.org/10.1177/1523422308328396

Johnson, S. D. 2012. Gay Affirmative Psychotherapy With Lesbian, Gay, and Bisexual Individuals: Implications for Contemporary Psychotherapy Research. American Journal of Orthopsychiatry, 82(4), 516-522. http://doi.org/ 10.1111/j.1939-0025.2012.01180.x

King, M., Semlyen, J., Tai, S. S., Killaspy, H., Osborn, D., Popelyuk, D., \& Nazareth, I. (2008). A systematic review of mental disorder, suicide, and deliberate self harm in lesbian, gay and bisexual people. BMC Psychiatry, 8, 70. http://doi.org/10.1186/1471-244X-8-70

Pan, P. L., Meng, J., \& Zhou, S. 2010. Morality or equality? Ideological framing in news coverage of gay marriage legitimization. Social Science Journal, 47(3), 630-645. http://doi.org/10.1016/j.soscij.2010.02.002

Roberts, E. 2001. Lesbian, gay, bisexual , and transgendered youth issues. SIECUS Report, 29(April/May), 37-42.

Silverstein, C. 1988. The Borderline Personality Disorder and Gay People. Joumal of Homosexuality, 15(1-2), 185-212. http://doi.org/10.1300/J082v15n01 